\title{
IAMJ
}

INTERNATIONAL

AYURVEDIC

MEDICAL JOURNAL

Research Article

ISSN: 2320-5091

Impact Factor: 6.719

\section{A COMPARATIVE CLINICAL STUDY TO EVALUATE THE EFFICACY OF SHUNTHYADI GUGGULU AND TRAYODASHANGA GUGGULU IN GRIDHRASI}

\section{$\underline{\text { Keerthana. }}^{1}$, $\underline{\text { Zenica D'souza }}^{2}$}

${ }^{1}$ P.G Scholar, Department of Kayachikitsa, Alva's Ayurveda Medical College and Hospital, Vidyagiri,

D.K, Karnataka, India

${ }^{2}$ Guide, Professor, Department of Kayachikitsa, Yenepoya Ayurveda Medical College and Hospital, Naringana, Mangaluru, Karnataka, India

Corresponding Author: keerthiayush94@gmail.com

https://doi.org/10.46607/iamj0709092021

(Published Online: September 2021)

Open Access

(C) International Ayurvedic Medical Journal, India 2021

Article Received: 24/08//2021 - Peer Reviewed: 03/09/2021 - Accepted for Publication: 04/09/2021

\section{Check for updates}

\begin{abstract}
Gridhrasi is a pain predominant Nanatmaja Vata Vyadhi characterised by radiating pain through Sphik, Kati, Prishtha, Uru, Janu, Jangha and Pada in a sequential pattern. A number of medicines are available in market to treat this condition, but are associated with their side effects too. Hence, there arises a need for an effective, yet safe treatment for the suffering population to ease their problems of pain. In light of these considerations a comparative clinical study was planned to assess and compare the efficacy of two formulations, namely Shunthyadi Guggulu and Trayodashanga Guggulu. Statistically significant changes were observed in the symptoms like Ruk, Stambha, Toda, Muhuspandana, Tandra, Gaurava, Aruchi, Time taken to cover the distance of 50ft, SLR Active and Passive test (Affected leg).
\end{abstract}

Keywords: Gridhrasi, Shunthyadi Guggulu, Trayodashanga Guggulu, Sciatica.

\section{INTRODUCTION}

The basic difference between the living and non-living is the ability to move from one place to another and it is hampered when an individual suffers from pain. A change in lifestyle and food habits along with 
increased possibilities of daily injuries even at the micro-level affects every system of the human body including the Musculoskeletal and Nervous systems. Gridhrasi, a Shoola Pradhana (shooting pain predominant) Nanatmaja Vata Vyadhi ${ }^{1}$ mentioned in Ayurveda explains one such disorder wherein, pain starts from Sphik Pradesh and radiates downwards to Kati, Prishtha, Uru, Janu, Jangha, Pada resulting with an inability of the patient to walk with ease. On the basis of symptoms, it can be correlated to Sciatica in modern medicine.

About 50 - $70 \%$ of people get affected by low back pain with the incidence of Sciatica more than $40 \%{ }^{2}$. Administration of Analgesics, NSAIDs, Corticosteroids, Muscle relaxants gives temporary relief from pain. The surgical measures which are indicated are quite expensive and result in several complications. So, there is a need for a cost-effective and safer drug having an established efficacy.

Considering these aspects, two Shamana Yoga were selected for the study. Shunthyadi Guggulu ${ }^{3}$ is mentioned in Vaidya Chintamani having ingredients like Shunti, Pippali, Devadaru, Rasna etc. Trayodashanga Guggulu is mentioned in Cakradatta having ingredients like Ashwagandha, Hapusa, Satapushpa, Yavani etc. Both these formulations possess Vata-Kaphahara, Deepana, Pachana properties and are indicated in Gridhrasi.

Hence, this study is a sincere effort made to evaluate and compare the effect of Shunthyadi Guggulu and Trayodashanga Guggulu in the management of Gridhrasi.

\section{OBJECTIVES OF THE STUDY: -}

- To evaluate the therapeutic effect of Shunthyadi Guggulu in Gridhrasi.

- To evaluate the therapeutic effect of Trayodashanga Guggulu in Gridhrasi.

- To compare the therapeutic effect of Shunthyadi Guggulu and Trayodashanga Guggulu in Gridhrasi.

MATERIAL AND METHODS

IEC NUMBER: ICEC/KC/02

DRUG SOURCE: Raw drugs were collected from the source of procurement after proper identification by experts. Medicines were prepared according to texts at Alva's Ayurveda Pharmacy, Mijar, Moodbidri.

SAMPLE SOURCE: Patients diagnosed with Gridhrasi were selected from the Outpatient Department and Inpatient Department of Post Graduate studies of Kayachikitsa, Alva's Ayurveda Medical College and Hospital, Moodbidri and also from Special medical camps and other referrals.

METHOD OF COLLECTION OF DATA: A case proforma was prepared with details of history taking, physical examination, necessary investigations and assessment parameters of signs and symptoms with their scores. This was analysed statistically.

SELECTION OF PATIENTS: Done irrespective of gender, religion, occupation, marital status, socio-economic status and educational status, fulfilling the diagnostic, inclusion and exclusion criteria of Gridhrasi. SAMPLE SIZE AND GROUPING - A minimum of 40 patients in total, randomly allocated into 2 arms A and $\mathrm{B}$ comprising minimum of 20 patients in each group.

STUDY DESIGN - Parallel Group Comparative Clinical Study.

BLINDING - Single Blind.

METHOD OF SAMPLING - Lottery Method. DIAGNOSTIC CRITERIA

1. Patients with radiating pain from Sphik and Kati to Prishtha, Uru, Janu, Jangha and Pada.

2. Stambha (Stiffness), Toda (Pricking Sensation), Muhuspandana (Tingling Sensation).

3. With or without Tandra (Drowsiness), Gaurava (Heaviness), Aruchi (Anorexia).

4. Positive SLR Test.

\section{INCLUSION CRITERIA}

1. Patients of age group between 20-60 years of either sex.

2. Patients fulfilling the diagnostic criteria as mentioned above.

\section{EXCLUSION CRITERIA}

1. Congenital, Neoplastic, Infective conditions of the spine.

2. Gridhrasi developed due to any post-surgical complications. 
3. Patients who have lost the control on bladder and defecation.

4. Patients with any other systemic disorders which were felt to interfere with the clinical trial.

5. Pregnant women and Lactating mothers.

\section{INTERVENTIONS}

GROUP A (Trial group): Shunthyadi Guggulu in the dose of 500mg 2 tablets thrice a day after food with Ushna Jala for 30 days.

GROUP B (Standard group): Trayodashanga Guggulu in the dose of 500mg 2 tablets thrice a day after food with Ushna Jala for 30 days.

\section{OBSERVATION PERIOD}

- Treatment period - 30 days.

- Follow up - 15 days after completing the course of treatment.

- $\quad$ Total study duration - 45 days $(30$ days +15 days).

- Days of assessments - Baseline, 16th day and after treatment i.e., on 31 st day.

\section{ASSESSMENT CRITERIA}

- Based on detailed case proforma adopting standard scoring methods of subjective and objective parameters.

- $\quad$ Statistical test of significance - Analysed using paired ' $\mathrm{t}$ ' test and unpaired ' $\mathrm{t}$ ' test along with other suitable statistical methods wherever necessary.

SUBJECTIVE PARAMETERS: Ruk, Stambha, Toda, Muhuspandana, Tandra, Gaurava, Aruchi

OBJECTIVE PARAMETERS: SLR test (Active and Passive) and Distance of walking (Time taken to cover the distance of $50 \mathrm{Ft}$ )

INVESTIGATIONS: Routine haematological investigations along with X-ray of Lumbo - Sacral Spine AP and Lateral views were carried out whenever found necessary.

STATISTICAL TEST: Comparative analysis of the overall effect of the treatments in both the groups was done statistically with Mann-Whitney Rank Sum Test and within the group comparison with Wilcoxon Signed Rank Test.

\section{RESULTS: -}

Table 1: Demographic details

\begin{tabular}{|l|l|l|}
\hline $\begin{array}{l}\text { Demographic } \\
\text { Characters }\end{array}$ & Highest Recorded & Reasons \\
\hline Age & $\begin{array}{l}41-50 \text { yrs. } \\
\text { Gender }\end{array}$ & $\begin{array}{l}\text { Susceptibility of productive population is proven by the statistics. } \\
\text { Man, to fulfil the needs of family, his body undergoes various kinds of stress } \\
\text { which finally lands up in this painful disorder. }\end{array}$ \\
\hline $\begin{array}{l}\text { Socioeconomic } \\
\text { status }\end{array}$ & $\begin{array}{l}50 \% \text { (Lower Middle } \\
\text { Class) }\end{array}$ & Due to subjective stress on the body secondary to their occupation. \\
\hline Occupation & $\begin{array}{l}40 \% \text { (Labour) } \\
80 \% \text { (Tea, Coffee, Al- } \\
\text { cohol) }\end{array}$ & $\begin{array}{l}\text { Nature of work has direct influence on the etiopathogenesis of Gridhrasi. } \\
\text { Addictions act as Vata vyadhi Nidana and further produce Vata prakopa pro- } \\
\text { ducing Gridhrasi. }\end{array}$ \\
\hline Nature of work & $\begin{array}{l}82.5 \% \text { (Moderate na- } \\
\text { ture of work) }\end{array}$ & $\begin{array}{l}\text { Physical strain is an important Vata Prakopa Nidana to land a person to } \\
\text { Gridhrasi. }\end{array}$ \\
\hline Prakruti & $\begin{array}{l}72.5 \% \text { (Vata }- \text { Kapha) } \\
\text { Susceptibility of persons with Vata as Prakruti to develop Vataja disorders } \\
\text { like Gridhrasi. }\end{array}$ \\
\hline Nature of Sleep & $\begin{array}{l}72.5 \% \text { (Disturbed } \\
\text { Sleep) }\end{array}$ & $\begin{array}{l}\text { It is quite evident that the character of pain in this disease disturbs the sleep } \\
\text { of the patient which in turn caused Vata Prakopa } .\end{array}$ \\
\hline
\end{tabular}


Table 2: Effect of Shunthyadi Guggulu in Subjective and Objective Parameters in Group A.

\begin{tabular}{|l|c|c|c|c|c|}
\hline CRITERIA & MEDIAN BT & MEDIAN AT & $\%$ & WSRT Value & p Value \\
\hline Ruk & 3.00 & 2.00 & 56.67 & 210.000 & $<0.001$ \\
\hline Stambha & 3.00 & 1.50 & 62.50 & 190.000 & $<0.001$ \\
\hline Toda & 3.00 & 1.00 & 50.00 & 210.000 & $<0.001$ \\
\hline Muhuspandana & 2.00 & 1.00 & 42.50 & 136.000 & $<0.001$ \\
\hline Tandra & 1.00 & 0.50 & 40.00 & 55.000 & $=0.002$ \\
\hline Gaurava & 1.00 & 0.50 & 48.28 & 55.000 & $=0.002$ \\
\hline Aruchi & 0.50 & 0.50 & 61.54 & 45.000 & $=0.004$ \\
\hline Time Taken to Cover the Distance Of 50ft & 3.00 & 1.00 & 59.62 & 210.000 & $<0.001$ \\
\hline SLR Test (Right Leg - Active) & 3.00 & 1.00 & 54.84 & 55.000 & $=0.002$ \\
\hline SLR Test (Right Leg - Passive) & 2.00 & 1.00 & 45.45 & 45.000 & $=0.004$ \\
\hline SLR Test (Left Leg - Active) & 3.00 & 1.50 & 50.00 & 55.000 & $=0.002$ \\
\hline SLR Test (Left Leg - Passive) & 2.00 & 1.00 & 47.62 & 36.000 & $=0.008$ \\
\hline
\end{tabular}

Table 3: Effect of Trayodashanga Guggulu in Subjective and Objective Parameters in Group B.

\begin{tabular}{|l|c|c|c|c|c|}
\hline CRITERIA & MEDIAN BT & MEDIAN AT & $\mathbf{\%}$ & WSRT Value & p Value \\
\hline Ruk & 3.00 & 2.00 & 51.52 & 210.000 & $<0.001$ \\
\hline Stambha & 3.00 & 1.00 & 60.00 & 210.000 & $<0.001$ \\
\hline Toda & 3.00 & 2.00 & 49.21 & 210.000 & $<0.001$ \\
\hline Muhuspandana & 2.00 & 1.00 & 45.83 & 171.000 & $<0.001$ \\
\hline Tandra & 0.00 & 0.00 & 43.75 & 15.000 & $=0.063$ \\
\hline Gaurava & 0.00 & 0.00 & 42.86 & 15.000 & $=0.063$ \\
\hline Aruchi & 0.00 & 0.00 & 57.14 & 10.000 & $=0.125$ \\
\hline Time Taken to Cover the Distance Of 50ft & 3.00 & 1.00 & 55.93 & 210.000 & $<0.001$ \\
\hline SLR Test (Right Leg - Active) & 3.00 & 1.00 & 56.67 & 55.000 & $=0.002$ \\
\hline SLR Test (Right Leg - Passive) & 2.00 & 1.00 & 50.00 & 55.000 & $=0.002$ \\
\hline SLR Test (Left Leg - Active) & 3.00 & 1.00 & 55.17 & 55.000 & $=0.002$ \\
\hline SLR Test (Left Leg - Passive) & 2.00 & 1.00 & 38.89 & 21.000 & $=0.031$ \\
\hline
\end{tabular}

Table 4: Comparative effect of Group A and Group B

\begin{tabular}{|l|c|c|c|c|c|c|}
\hline Assessment Criteria & Group A & Group B & A - B & \multicolumn{2}{l|}{ Percentage Relief } & p Value \\
\hline Ruk & & & & Group A & Group B & \\
\hline Stambha & 2.000 & 2.000 & 0.000 & 56.67 & 51.52 & $<0.05$ \\
\hline Toda & 1.000 & 2.000 & 1.000 & 62.50 & 60.00 & $>0.05$ \\
\hline Muhuspandana & 2.000 & 2.000 & 0.000 & 50.00 & 49.21 & $>0.05$ \\
\hline Tandra & 1.000 & 1.000 & 0.000 & 42.50 & 45.83 & $>0.05$ \\
\hline Gaurava & 0.500 & 0.000 & 0.500 & 40.00 & 43.75 & $>0.05$ \\
\hline Aruchi & 0.500 & 0.000 & 0.500 & 48.28 & 42.86 & $>0.05$ \\
\hline Time is taken to cover the distance of 50 Ft & 0.000 & 0.000 & 0.000 & 61.54 & 57.14 & $>0.05$ \\
\hline SLR Test - Rt. Leg (Active) & 2.000 & 2.000 & 0.000 & 59.62 & 55.93 & $<0.05$ \\
\hline SLR Test - Rt. Leg (Passive) & 2.000 & 2.000 & 0.000 & 54.84 & 56.67 & $>0.05$ \\
\hline SLR Test - Lt. Leg (Active) & 1.000 & 1.000 & 0.000 & 45.45 & 50.00 & $>0.05$ \\
\hline SLR Test - Lt. Leg (Passive) & 2.000 & 1.000 & 1.000 & 50.00 & 55.17 & $>0.05$ \\
\hline
\end{tabular}


Table 5: Overall effect: -

\begin{tabular}{|l|l|l|}
\hline Group & Grading & No. of patients \\
\hline Group A & $\begin{array}{l}\text { Moderate } \\
\text { improvement }\end{array}$ & 1 \\
\cline { 2 - 3 } & $\begin{array}{l}\text { Marked } \\
\text { improvement }\end{array}$ & 19 \\
\hline Group B & $\begin{array}{l}\text { Moderate } \\
\text { improvement }\end{array}$ & 13 \\
& $\begin{array}{l}\text { Marked } \\
\text { improvement }\end{array}$ \\
\hline
\end{tabular}

\section{DISCUSSION}

\section{DISCUSSION ON RESULTS AND MODE OF} ACTION OF DRUGS: -

SHUNTHYADI GUGGULU is mentioned in Vaidya Chintamani having ingredients like Sunthi has Katu Rasa; Guru, Ruksha, Tikshna Gunas; Usna Virya; Madhura Vipaka; Vata-kaphahara, Dipana properties and it acts on Sula. Anti-inflammatory, Anti-emetic ${ }^{5}$. Pippali has Katu Rasa; Laghu, Snigdha, Tikshna Gunas; Usna Virya; Madhura Vipaka; Vata-Sleshmahara, Dipana properties and it acts on Sula. Anti-inflammatory, Anti-bacterial ${ }^{6}$. Pippali Mula has Katu Rasa; Laghu, Ruksha Gunas; Usna Virya; Katu Vipaka; Kapha-Vatahara, Dipana and Pachana properties. Anti-inflammatory, Anti-bacterial, Anti-helmintic ${ }^{7}$. Vidanga has Katu, Kashaya Rasas; Laghu, Ruksha, Tikshna Gunas; Usna Virya; Katu Vipaka; Dipana property and it acts on Sula. Insecticidal, Antimalarial ${ }^{8}$. Devadaru has Tikta, Katu, Kashaya Rasas; Ruksha, Laghu Gunas; Usna Virya; Katu Vipaka; Kapha-Vatahara, Dipana properties. Spasmolytic ${ }^{9}$. Saindhava Lavana has Madhura Rasa; Snigdha, Laghu Gunas; Sheeta Virya; Tridosha Hara, Rochana, Dipana property and it acts on Aruchi ${ }^{10}$. Rasna has Tikta Rasa; Guru Guna; Usna Virya; Katu Vipaka and Kapha-Vatahara property. Anti-oedema, Analge$\mathrm{sic}^{11}$. Chitraka has Katu Rasa; Laghu, Ruksha, Tikshna Gunas; Usna Virya; Katu Vipaka; Vata-kaphahara, Dipana, Pachana properties and it acts on Sula. Anti-pyretic, Appetizer ${ }^{12}$.Yavani has Katu Rasa; Laghu, Ruksha, Tikshna Gunas; Usna Virya; KaphaVatahara, Dipana, Pachana properties and it acts on Sula. Antioxidant ${ }^{13}$. Marica has Katu Rasa; Laghu, Tikshna Gunas; Usna Virya; Katu Vipaka; Kapha-
Vatahara, Dipana properties and it acts on Sula. Sedative, Analgesic, Muscle relaxant ${ }^{14}$. Vacha has Katu, Tikta Rasas; Laghu, Tikshna Gunas; Usna Virya; Katu Vipaka; Kapha-Vatahara property. Analgesic ${ }^{15}$. Haritaki has Pancharasas; Laghu, Ruksha Gunas; Usna Virya; Madhura Vipaka; Tridoshahara, Anulomana properties and it acts on Sotha. Anti-stress, Antispasmodic $^{16}$. Guggulu has Tikta, Katu Rasas; Laghu, Ruksha Gunas; Usna Virya; Katu Vipaka; Tridoshahara property it acts on Vata vyadhi, Sotha. Anti-oedema, Anti-inflammatory ${ }^{17}$.

TRAYODASHANGA GUGGULU is mentioned in Cakradatta having ingredients like Abha has Kashaya Rasa; Guru, Ruksha Gunas; Sita Virya; Katu Vipaka; Kaphahara, Lekhana and Grahi properties. Anti-constipative $^{18}$. Ashwagandha has Katu, Tikta, Kashaya Rasas; Snigdha, Laghu Gunas; Usna Virya; Katu Vipaka; Vata-kaphahara properties and it acts on Sotha. Antioxidant ${ }^{19}$. Hapusa has Katu, Tikta Rasas; Guru Guna; Usna Virya; Katu Vipaka; Vata-kaphahara, Dipana properties and it acts on Sula. Anti-spasmodic, Anti-oedema ${ }^{20}$. Guduchi has Tikta, Kashaya Rasas; Guru, Snigdha Gunas; Usna Virya; Madhura Vipaka; Tridosha shamaka, Dipaniya, Grahi and it acts on Sula. Anti-stress, Anti-spasmodic ${ }^{21}$. Satavari has Madhura, Tikta Rasas; Guru, Snigdha Gunas; Sita Virya; Madhura Vipaka; Vata-pittahara property. Antioxidant $^{22}$. Gokshura has Madhura Rasa; Guru, Snigdha Gunas; Sita Virya; Madhura Vipaka; Vatapittahara property. Spasmogenic, Analgesic ${ }^{23}$. Vriddhadaraka has Kashaya, Katu, Tikta Rasas; Laghu, Snigdha Gunas; Usna Virya; Madhura Vipaka; Vatakaphahara property and it acts on Sotha. Anti-inflammatory ${ }^{24}$. Rasna has Tikta Rasa; Guru Guna; Usna Virya; Katu Vipaka and Kapha-Vatahara property. Antiinflammatory, Anti-oedema ${ }^{25}$. Shatapushpa has Katu, Tikta Rasas; Laghu, Tikshna Gunas; Usna Virya; Katu Vipaka; Vata-kaphahara, Dipana properties and it acts on Sula. Antioxidant ${ }^{26}$. Sathi has Katu, Tikta, Kashaya Rasas; Laghu, Tikshna Gunas; Usna Virya; Katu Vipaka; Kapha-Vatahara property and it acts on Sula. Anti-emetic, Anti-inflammatory ${ }^{27}$. Yavani has Katu Rasa; Laghu, Ruksha, Tikshna Gunas; Usna Virya; Kapha-Vatahara, Dipana, Pachana properties 
and it acts on Sula. Antioxidant, Hypolipidemic ${ }^{28}$. Sunthi has Katu Rasa; Guru, Ruksha, Tikshna Gunas; Usna Virya; Madhura Vipaka; Vata-kaphahara, Dipana properties and it acts on Sula. Anti-inflammatory, Anti-atherosclerotic ${ }^{29}$. Guggulu has Tikta, Katu Rasas; Laghu, Ruksha Gunas; Usna Virya; Katu Vipaka; Tridoshahara property it acts on Vata vyadhi, Sotha. Anti-oedema, Spasmolytic ${ }^{30}$. Ghrita has Madhura Rasa; Guru, Snigdha Gunas; Mrudu Veerya; Madhura Vipaka; Vata-pittahara property. Antioxidant $^{31}$.

Dropouts: 2 patients in Group A discontinued the treatment due to their personal reasons.

\section{CONCLUSION}

40 Patients having the Signs and Symptoms of Gridhrasi / Sciatica and who were in the age group of 20 - 60 yrs. who attended the OPD and IPD of Alva's Ayurveda Medical College and Hospital were subjected to Parallel Group Comparative Clinical Study and were treated with Shunthyadi Guggulu and Trayodashanga Guggulu. After completion of the study, the following are the conclusions drawn.

- Gridhrasi is one among the Vataja Nanatmaja Vyadhi, Vataja and Vatakaphaja are the clinical types.

- Stiffness, pain and pricking sensation beginning from the buttock and then sequentially progressing to the back of the pelvis, hip, thigh, knee, leg and feet is the cardinal manifestation of the Gridhrasi.

- The clinical symptoms of Gridhrasi match with Sciatica of modern parlance.

- Mithyacharana of Vyayama was found to be a triggering factor in the pathogenesis of this disease.

- Clinical: Clinically, Group A - Shunthyadi Guggulu and Group B - Trayodashanga Guggulu equally showed effective changes in attributes within the group. When groups were compared there was no significant difference in results.

- Statistical: Statistically significant changes were observed in the symptoms like Ruk, Stambha, Toda, Muhuspandana, Tandra, Gaurava, Aruchi,
Time taken to cover the distance of 50ft, SLR Active and Passive test (Affected leg).

- From the above data and discussion, it can be concluded that both Shunthyadi Guggulu and Trayodashanga Guggulu are equally effective in relieving the signs and symptoms with the mild difference in terms of percentage in Gridhrasi.

- Treatment of Shunthyadi Guggulu is curative in patients suffering from Gridhrasi as the study revealed 19 patients had marked improvement and 1 patient had moderate improvement.

- Trayodashanga Guggulu study revealed moderate improvement in 13 patients and marked improvement in 7 patients.

- Both groups are effective in the remission of the symptoms of Gridhrasi as evidenced by a statistically significant reduction in the symptom score. So, hypothesis $\mathrm{H} 1$ is rejected and $\mathrm{H} 0$ is accepted.

- Patient Tolerance: There were no adverse effects found in the groups. Therefore, these formulations are effective and safe to be used in clinical practice.

- Quality of life is improved by both the medications as shown by improvement of functional ability, as well as a reduction in functional disability.

\section{Suggestions for further studies:}

- The research can be done in a larger sample size to evaluate the efficacy of Shamana Aushadhi's (Palliative treatment) in Gridhrasi.

- The study can be carried by undertaking radiological investigations like MRI, NCS.

- The subjects may be preferred to be treated in an IPD set-up, to obtain a comprehensive evaluation of both disease and diseased.

\section{REFERENCES}

1. Narayana AN. A Clinical to evaluate the therapeutic effect of Navajeevana rasa in Gridhrasi (Unpublished Doctoral dissertation, RGUHS, Karnataka,2002-03).

2. Deepthi MS. A Clinical study on the management of Gridhrasi, with Gandharvahastadi tail and vatari Guggulu (Unpublished Doctoral dissertation, RGUHS, Karnataka,2006). 
3. Ramachandra R. To evaluate the therapeutic effect of Kati Basti in patients of Gridhrasi (Unpublished Doctoral dissertation, RGUHS, Karnataka, 2003- 04).

4. Vargese Jibi T. A clinical study to evaluate the effect of vatagajankusha rasa in Gridhrasi (Unpublished Doctoral dissertation, RGUHS, Karnataka,2008- 09).

5. Jain Shailesh. A comparative clinical study on the effect of vatari Guggulu \& Kati vasti in Gridhrasi (Unpublished Doctoral dissertation, RGUHS Karnataka, 2011-12).

6. Agnivesha. Charaka samhita, elaborated by Charaka \& Dridhabala with Ayurveda deepika commentary by Chakrapani Datta, Vaidya Yadavji Trikamji Acharya ed., Varanasi; Chaukambha Sanskrit Sansthana;2007 reprint 738; Pg. no 110.

7. Agnivesha. Charaka Samhita, elaborated by Charaka \& Dridhabala with Ayurveda deepika commentary by Chakrapani Datta, Vaidya Yadavji Trikamji Acharya ed., Varanasi; Chaukambha Sanskrit Samsthana, 2008 edition 738; Pg. no 43.

8. Agnivesha. Charaka Samhita, elaborated by Charaka \& Dridhabala with Ayurveda deepika commentary by Chakrapani Datta, Vaidya Yadavji Trikamji Acharya ed., Varanasi; Chaukambha Sanskrit Samsthana, 2008 edition. Pp 738; Pg. no 619.

9. Sushruta. Sushrutha samhita, elaborated by Dalhanacharya with a commentary by Dalhanacharya and Nyayachandrika Panjika of Gayadasa, Vaidya Yadavji Trikamji Acharya, Narayana ram acharya ed., Varanasi; Chaukambha Orientalia, 2007 edition 824; Pg. no 268.

10. Sushruta. Sushrutha samhita, elaborated by Dalhanacharya with a commentary by Dalhanacharya and Nyayachandrika Panjika of Gayadasa, Vaidya Yadavji Trikamji Acharya, Varanasi; Chaukambha Orientalia, 2007 edition 824; Pg. no 361.

11. Sushruta. Sushrutha samhita, elaborated by Dalhanacharya with a commentary by Dalhanacharya and Nyayachandrika Panjika of Gayadasa, Vaidya Yadavji Trikamji Acharya, Narayana ram acharya ed., Varanasi; Chaukambha Orientalia, 2007 edition 824; Pg. no 268.

12. Vagbhata. Astanga Sangraha, with a commentary Sasilekha of Indu, with Sanskrit English prologue by Dr Jyotirmitra acharya, Vaidya Yadavji Trikamji Acharya, Dr Shiva prasad Sharma ed., Varanasi; Chaukambha Sanskrit series, 2008 edition 935; Pg. no 148.

13. Vagbhata. Astanga Sangraha, with a commentary Sasilekha of Indu, with Sanskrit English prologue by Dr
Jyotirmitra acharya, Vaidya Yadavji Trikamji Acharya, Dr Shiva prasad Sharma ed., Varanasi; Chaukambha Sanskrit series, 2008 edition. Pp 935; Pg. no 412.

14. Vagbhata. Astanga Sangraha, with a commentary Sasilekha of Indu, with Sanskrit English prologue by Dr Jyotirmitra acharya, Vaidya Yadavji Trikamji Acharya, Dr Shiva prasad Sharma ed., Varanasi; Chaukambha Sanskrit series, 2008 edition. Pp 935; Pg. no 246.

15. Vagbhata. Astanga Hridaya, with a commentary Sarvanga Sundara of Arunadatta and Ayurveda Rasayana of Hemadri, Pt. Harisadashiva Shastri Paradakara ed., Varanasi; Chaukambha Sanskrit Sansthan, 2010reprint, Pp 956; Pg. no 535.

16. Vagbhata. Astanga Hridaya, with a commentary Sarvanga Sundara of Arunadatta and Ayurveda Rasayana of Hemadri, Pt. Harisadashiva Shastri Paradakara ed., Varanasi; Chaukambha Sanskrit Sansthan, 2010 reprint, Pp 956; Pg. no 328.

17. Vagbhata. Astanga Hridaya, with a commentary Sarvanga Sundara of Arunadatta and Ayurveda Rasayana of Hemadri, Pt. Harisadashiva Shastri Paradakara ed., Varanasi; Chaukambha Sanskrit Sansthan, 2010 reprint, Pp 956; Pg. no 535.

18. Kashyapa. Kashyapa Samhita, elaborated by Vriddha Jivaka, vatsya, Dr. p v Tiwari ed., Varanasi; Chaukambha Vishwa Bharati, 2013 reprint, Pp 792; Pg. no 68 .

19. Bhela. Bhela Samhita, with English translation commentary critical notes, prof p v Sharma ed., Varanasi; Chaukambha Bharati academy, 2008 reprint. Pp 660; Pg. no 454.

20. Madhavakar. Madhava nidana, with Madhukosha commentary by Vijayarakshita and Srikanth Datta, Vaidya Yadavji Trikamji Acharya ed., part 1, Varanasi; Chaukambha Orientalia, 2001 edition. Pp 412; Pg. no 175.

21. Chakrapani Datta. Chakradatta, with English text and translation, p v Sharma ed., Varanasi; Chaukambha Sanskrit sansthan, 2007 reprint. Pp 731; Pg. no 183.

22. Harita, Harita Samhita, with Nirmala Hindi commentary, Vaidya Jatymini Pandey ed., Varanasi; Chaukambha Bharati academy, 2010 edition. pp544; Pg. no.381.

23. Shodala, Gada nigraha, part 1 prayoga khanda, with Vidyotini hindi commentary by indradev tripathi, gangasahaya pandeya ed., Varanasi; Chaukambha Sanskrit sansthan, 2003 edition. pp416; pg. 261.

24. Shodala, Gada nigraha, part 2kayachikitsa khanda, with Vidyotini hindi commentary by indradev tripathi, 
gangasahaya pandeya ed., Varanasi;2005 reprint.

Chaukambha Sanskrit sansthan, pp871; pg 486.

25. Vangasena. Vangasena Samhita, with English translation, notes, historical introduction, comments, volume 1, Nirmala Saxena, Varanasi; Chaukambha Sanskrit series office, 2004 edition 669;pg404.

26. Sharangdhara. Sarangadhara Samhita, translation by Dr. p Himasagara Murthy, Varanasi; Chaukambha Sanskrit series office, 2013 reprint 454; pg. no 85.

27. Sarangadhara. Sarangadhara Samhita, translation by Dr. p Himasagara Murthy, Varanasi; Chaukambha Sanskrit series office, 2013 reprint 454, pg. no 111;147.

28. Vagbhata. Rasaratna samuchaya., with a siddhi Prada hindi commentary Sasilekha by Siddhinanadan Mishra, Varanasi; Chaukambha Orientalia, 2011 edition 935; Pg no 148.

29. Bhavmishra. Bhavaprakasha, with Vidyotini Hindi commentary by pandit Sri Brahma Shankar Mishra, part 2, Madhyama khanda, pandit Sri Brahma Shankar Mishra ed., Varanasi; Chaukambha Sanskrit Sansthan, 2013 edition 836; Pg no 241.

30. Yogaratnakara, Vaidyaprabha Hindi commentary by Dr Andrade Tripathi, Dr Dayashankar Tripathi ed., Varanasi; Chaukambha Krishnadas academy, 2011 edition. Pp 894; Pg no 400.

31. Govinda das Sen, Bhaishajya Ratnavali, with siddhi Prada Hindi commentary by Siddhinanadan Mishra, Varanasi; Chaukambha Surbharati Prakashana, 2007 reprint 1196; Pg no 518.

\section{Source of Support: Nil \\ Conflict of Interest: None Declared}

How to cite this URL: Keerthana. S \&Zenica D'souza: A Comparative Clinical Study To Evaluate The Efficacy Of Shunthyadi Guggulu And Trayodashanga Guggulu In Gridhrasi. International Ayurvedic Medical Journal \{online\} 2021 \{cited September 2021\} Available from: http://www.iamj.in/posts/images/upload/1966_1973.pdf 